\title{
ДИНАМІКА ЗМІН У РОЗВИТКУ ЕМОЦІЙНОї \\ КОМПЕТЕНТНОСТІ СТУДЕНТІВ-МЕДИКІВ ЯК РЕЗУЛЬТАТ \\ ВПРОВАДЖЕННЯ СПЕЦКУРСУ ТА ЗАСТОСУВАННЯ \\ ТРЕНІНГОВИХ ПСИХОТЕХНОЛОГІЙ
}

УДК: 159.942 .2

\begin{abstract}
Лазуренко Олена Олексіӥвна
Старший викладач кафедри загальної і медичної психології та педагогіки Національного медичного університету імені О.О. Богомольия,

м. Київ (Украӥна)
\end{abstract}

\begin{abstract}
Анотація. У статті розглянуто особливості професійної підготовки майбутнього лікаря. Представлена сучасна концепџія формування емочійної компетентності на різних етапах професійної підготовки у вищому медичному навчальному закладі. Виділено психолого-педагогічні складові моделі формування емоційної компетентності майбутнього лікаря у структурі навчального процесу. Запропонована програма тренінгу та описано результати впровадження програми формування емоційної компетентності майбутнього лікаря. Викладено загальну стратегію, структуру, розкриті головні принциии, методичні підходи та зміст тренінгової програми, спрямованої на формування емочійної компетентності студентів - майбутніх лікарів. Проаналізовано результати експериментальної перевірки застосування тренінгової програми та кількісні зміни у показниках складових емоційної компетентності. Продемонстровано позитивну динаміку змін у розвитку емоційної сфери студентів-медиків в результаті застосування тренінгових психотехнологій, а відтак, підвищення рівня розвитку компетенцій студентівмедиків у сфері емоиій. Доведено ефективність запропонованої програми формування всіх компонентів емоційної компетентності майбутніх лікарів. Зроблено висновки та сформовано перспективи подальших наукових досліджень.
\end{abstract}

Ключові слова: емоційна компетентність, розвиток, майбутній лікар, спецкурс,

тренінг, професійна підготовка.

\section{Постановка проблеми та її зв'язок 3} важливими практичними завданнями. Особистісний розвиток студента, формування його готовності до майбутньої професійної діяльності є важливими чинниками в оптимізації навчального процесу у вищих закладах освіти на сучасному етапі розвитку суспільства. В свою чергу, навчально-виховний процес у вищому медичному навчальному закладі $\epsilon$ невід‘ємною складовою частиною розвитку особистості студента - майбутнього лікаря, що сприяє формуванню його професіоналізму. 3 огляду на це, доцільно припустити, що одним з основних завдань навчання і виховання, ре- 
зультатом професійного становлення фахівця у вищому медичному навчальному закладі $\epsilon$ формування його компетентності. Важливим $€$ й той факт, що в процесі професійної психологічної підготовки медичних кадрів вивчення суттєвих емоційних властивостей, формування емоційної компетентності майбутніх лікарів є одним з провідних завдань, адже засвоєння найсуттєвіших експресивних якостей людини призводить до сприятливих умов спілкування лікаря з пацієнтом.

Вивчення сучасного стану професійної підготовки майбутнього лікаря свідчить, що вирішенню зазначеного завдання вищими навчальними закладами приділяється недостатня увага. Результати аналізу навчальних планів та програм підготовки медичних фахівців свідчать, що психологія емоцій не виділяється в окремий об‘єкт педагогічного впливу, а тому існує об'єктивна суперечність між реальною потребою майбутнього фахівця в оволодінні знань 3 психології емоцій та можливістю отримати їх у процесі навчання у вищому медичному навчальному закладі [2, с. 113-117]. Розв'язати цю суперечність, на наше глибоке переконання, можна шляхом формування емоційної компетентності майбутнього фахівця, оскільки акумулює в собі як професійну компетентність, так і індивідуальні властивості особистості.

Актуальність дослідження зумовлена тим фактом, що на сьогодні проблема формування емоційної компетентності майбутнього фахівця є новою в галузі психологічних досліджень. Однак, на наше глибоке переконання, доцільно з'ясувати, яким чином вирішується дана проблема в практиці вищої медичної освіти. Враховуючи велику професійну важливість формування емоційної компетентності постала проблема пошуку певних потенціалів професійної підготовки у іï розв'язанні. Вважаємо за доречне з'ясувати, які необхідно отримати знання в галузі емоцій, якими оволодіти вміннями, навичками в процесі професійної підготовки у вищому навчальному закладі $з$ метою формування емоційної компетентності майбутнього лікаря.

\section{Аналіз останніх досліджень і публі-}

кацій. Значна частина досліджень емоційної сфери присвячена ролі емоцій та емоційних переживань у різних видах діяльності людини, життєвих ситуаціях. Вивченню окремих аспектів емоційної компетентності присвячені праці I. Андреєвої, I. Аршави, Д. Гоулмана, В.Н. Куніцина, Е. Носенко, К. Саарні, О. Саннікової, В. М. Холмогорова, S. Denham, R. Weissberg, T. Shriver та ін. Проте, незважаючи на безліч проведених досліджень, безперечну актуальність і практичну значимість, огляд літератури з очевидністю показує слабку вивченість сутності емоційної сфери в рамках психології та педагогіки вищої медичної школи, а проблема емоційної компетентності лікарів та ії вплив на професійну діяльність залишається недостатньо дослідженою і нині. Сьогодні розроблені і вже використо- 
вуються різні вправи, завдання, семінари, практикуми, спрямовані на розвиток емоційної сфери, формування емоційної компетентності студента, які можуть бути використані в якості додаткового матеріалу в процесі теоретичної і практичної підготовки майбутнього лікаря у вищому медичному навчальному закладі. Слід зазначити, що пропонуються нові підходи, спрямовані, в першу чергу, на розвиток індивідуальних властивостей особистості фахівця. 3 цієї точки зору, проблема формування емоційної компетентності лікаря, на жаль, не розглядалась.

Виділення невирішених раніше частин загальної проблеми, якій присвячусться стаття. На наш погляд, необхідно знайти такий підхід, вибудувати таку програму, яка зможе забезпечити розвиток індивідуальності фахівця, зокрема формування його емоційної компетентності протягом всього процесу навчання у вищому медичному навчальному закладі. Найбільш перспективними, з нашої точки зору, шляхами вирішення поставлених завдань у навчально-виховному процесі вищого медичного навчального закладу мають стати не лише інтеграція навчальних дисциплін соціально-гуманітарного циклу, а і впровадження спеціально розроблених елективних (вибіркових) курсів, застосування сучасних тренінгових технологій. Таким чином, припускаємо, що систематизовані тренінгові заняття, спрямовані на розвиток психологічних особливостей емоційної компетентності май- бутнього лікаря, допоможуть у формуванні емоційної компетентності, як в цілому, так i окремих ii компонентів (когнітивного, соціального, регулятивного та емпатійного).

Мета статті: після грунтовних теоретичних і практичних досліджень представити аналіз емпіричного дослідження та динаміку змін у розвитку психологічних особливостей емоційної компетентності майбутнього лікаря в результаті впровадження спеціальної програми із формування іiі структурних компонентів.

Виклад основного матеріалу дослідження. Одним із завдань нашого дослідження була розробка програми формування емоційної компетентності майбутнього лікаря в процесі професійної підготовки. Метою створення цієї концептуальної програми формування емоційної компетентності майбутнього лікаря була необхідність у підготовці кваліфікованих фахівців у галузі медицини з високим рівнем розвитку емоційних якостей [7, с. 124129], а також розвиток основних структурних компонентів емоційної компетентності лікаря (когнітивний, соціальний, регулятивний та емпатійний компоненти).

Моделювання процесу формування емоційної компетентності майбутнього лікаря передбачало впровадження спеціальної програми, що включало ряд послідовних етапів: теоретична підготовка, вивчення дисциплін, коли відбувається оволодіння студентами теоретичними знаннями з основ емоційної сфери; 
впровадження спеціального курсу 3 метою оволодіння студентами емпіричними знаннями 3 основ емоційної сфери, усвідомлення студентами ролі емоційної компетентності у професійній діяльності лікаря (курс «Психологія емоцій») [1, с. 22-25]; для закріплення практичних навичок - тренінг «Формування емоційної компетентності», спрямований на пізнання особливостей власної емоційної сфери, розвиток емоційної виразності, регуляція емоційних станів, застосування студентами набутих знань, умінь у навчально-пізнавальному процесі [4, с. 106114.]; а також на заключному етапі - застосування набутих знань, корекція умінь і відпрацювання навичок з основ емоційної компетентності у процесі практичної діяльності (практикум професійних навичок). Основним результатом впровадження даної психологічної програми формування емоційної компетентності майбутнього лікаря є підвищення рівня розвитку компетенцій студентів-медиків у сфері емоцій. Мова йде про позитивну динаміку розвитку емоційної компетентності та ії структурних компонентів у студентів - майбутніх лікарів, розвиток навичок усвідомлення, управління, контролю своїх емоцій та емоцій інших, розвиток емпатії, підвищення самооцінки, впевненості у собі тощо.

Проведене нами лонгитюдне дослідження, передбачало наступні кроки. Так, на першому етапі - організаційно-пошуковому вирішення завдань, пов“язаних із досліджен- ням проблеми емоцій та емоційної компетентності у психології, формування емоційної компетентності майбутнього лікаря в практиці вищої медичної школи, а також з'ясування можливостей формування емоційної компетентності в процесі професійної підготовки у вищих медичних навчальних закладах освіти. На другому - експериментальному - етапі відбувалось вивчення психологічних особливостей емоційної компетентності студентів майбутніх лікарів. На цьому етапі нами здійснювався вибір психодіагностичного інструментарію для проведення емпіричного дослідження, проводилось тестування з метою діагностики психологічних особливостей емоційної компетентності, проводилась статистична обробка отриманих результатів, інтерпретація емпіричних даних. На третьому - заключному етапі - впровадження спеціальної програми формування емоційної компетентності майбутнього лікаря в процесі професійної підготовки відповідно до розробленої нами моделі та діагностика та оцінка результатів впровадження цієї програми [5, с. 97-106.].

Дослідження проводилось на базі Національного медичного університету імені О.О. Богомольця зі студентами та інтернами медико-психологічного, стоматологічного, фармацевтичного та медичних факультетів. В експерименті взяли участь 328 майбутніх лікарів різних курсів, двох статей віком від 17 до 32 років. У складі сформованої вибірки представлено 67 осіб. 
Нами було розроблено та впроваджено у навчальний процес курс (вибіркову дисципліну) «Психологія емоцій» для всіх спеціальностей. Цей курс спрямований на вдосконалення знань у сфері емоцій, що знаходить своє відображення як у теоретичній, так i практичній складових вивчення даної дисципліни. Мета курсу полягає у всебічному вивченні психологічної сутності емоційної сфери особистості та засвоєнні основних іiї властивостей, зокрема, функціонування і характеристики емоційних станів. Навчальний матеріал сконцентрований на усвідомленні студентами власних емоційних станів в умовах аудиторних занять, формування знань про основні особливості емоційної сфери особистості, вікові особливості іiі емоційної сфери; формування вмінь розпізнавати емоційні стани та адекватного розуміння власних емоційних особливостей, прагнення до їх самовдосконалення; визначення сприятливих факторів власного емоційного розвитку та ролі емоційного фактору у професійній діяльності майбутнього лікаря, у виникненні та лікуванні психічних і психосоматичних захворювань, а також усвідомити необхідність врахування емоційного стану в процесі лікування, тощо.

Доцільність проведення тренінгових занять 3 формування емоційної компетентності майбутнього лікаря обумовлена теоретичним аналізом та результатами проведеного експериментального дослідження. Результатом проведення тренінгу було підвищення рі- вня розвитку емоційних компетенцій лікаря, формування позитивного емоційного ставлення до подальшого саморозвитку в сфері емоцій.

Проаналізуємо результати дослідження, а також динаміку змін у розвитку психологічних особливостей структурних компонентів емоційної компетентності майбутнього лікаря після впровадження спеціальної програми із застосуванням тренінгових психотехнологій.

3 метою визначення психологічних особливостей (складових компонентів) емоційної компетентності студентів - майбутніх лікарів було використано комплекс методик, що відповідають завданням нашого наукового пошуку: опитувальник «Емоційного інтелекту (ЕмІн)» Д. В. Люсіна, методика діагностики емоційного інтелекту Н. Холла, методика визначення загальної емоційної спрямованості особистості (Б. В. Додонов), методика діагностики рівня емпатійних здібностей (В. В. Бойко), методика діагностики перешкод у встановленні емоційних контактів (В. В. Бойко). Зупинимося на аналізі результатів дослідження, отриманих за кожною методикою окремо $[6$, с. 96-111.].

Після впровадження програми формування емоційної компетентності для майбутніх лікарів показники рівня розвитку психологічних складових емоційної компетентності за методикою Н. Холла суттєво змінились. Як показали результати співставлення середніх 
показників прояву складових емоційного інтелекту у студентів (2 та 3 етапи дослідження), практично за всіма шкалами: емоційна обізнаність, управління своїми емоціями, самомотивація, емпатія, розпізнавання емоцій інших ми отримали значно вищі кількісні результати, ніж на констатуючому етапі дослідження. Так, зміни в середніх показниках по шкалі становили 6,84, що відповідало низькому рівню, відповідно за методикою Холла. На 3 етапі дослідження цей показник змінився $(9,38)$ i став відповідати середньому рівню. Що стосується шкали «Управління своїми емоціями», то на 2 етапі вона кількісно була мало вираженою - середній показник становив всього 0,42 , що, на нашу думку, свідчило про не сформо-

Таблиця 1

\section{Порівняльна характеристика рівня прояву складових емоційного інтелекту у студентів (2 та 3 етапи дослідження) за методикою Н. Холла}

\begin{tabular}{|l|c|c|}
\hline \multicolumn{1}{|c|}{ Шкали } & $\begin{array}{c}\text { 2 етап дослідження } \\
\text { (середні показники) }\end{array}$ & 3 етап дослідження \\
\hline Емоційна обізнаність & 9,33 & 12,61 \\
\hline Управління своїми емоціями & 0,42 & 5,8 \\
\hline Самомотивація & 6,84 & 9,38 \\
\hline Емпатія & 8,3 & 12,5 \\
\hline Розпізнавання емоцій інших лю- & 8,1 & 11,3 \\
\hline Загальний рівень & $\mathbf{3 2 , 7 5}$ & $\mathbf{5 1 , 6 1}$ \\
\hline
\end{tabular}

«Емоційна обізнаність» хоча і залишилися на середньому рівні, разом $з$ тим показали позитивну якісну динаміку (9,33 - на 2 етапі та 12,61 - на 3 етапі). Така ж динаміка спостерігалася і в порівнянні кількісних показників за шкалами «Емпатія» $(8,3$ - на 2 етапі та 12,5 на 3 етапі) та «Розпізнавання емоцій інших» (8,1 - на 2 етапі та 11,3 - на 3 етапі). Найбільш виражені кількісні зміни відбулися i у шкалах «Самомотивація» та «Управління своїми емоціями». Середні показники за шкалою «Самомотивація» на 2 етапі дослідження ваність даної характеристики у майбутніх лікарів і відповідало дуже низькому рівню. На 3 етапі дослідження цей показник теж кількісно змінився $(5,8)$, хоча і надалі залишився на низькому рівні і потребує подальшого розвитку (Таблиця 1) .

На третьому етапі дослідження для більш глибокого аналізу сформованості у майбутніх лікарів складових емоційного інтелекту нам також була проведена методика «Емоційного інтелекту (ЕмІн)» Д. В. Люсіна. Різні аспекти міжособистісного емоційного 
інтелекту (MEI) аналізувалися нами за кількісними показниками двох субшкал: розуміння чужих емоцій та управління чужими емоціями, а різні аспекти внутрішньоособистісного емоційного інтелекту (BEI) за кількісними показниками трьох субшкал: розуміння своїх емоцій, управління своїми емоціями, контроль експресії. Дослідження емоційного інтелекту здійснювалось в кількох напрямках: аналіз середніх показників прояву складових міжособистісного емоційного інтелекту та внутрішньоособистісного емоційного інтелекту, визначення загального рівня міжособистісного та внутрішньоособистісного емоційного інтелекту, а також характеристика загального по- казника рівня емоційного інтелекту. Такий підхід дозволив нам детально представити кількісні характеристики емоційного інтелекту за всіма шкалами та субшкалами та на цій основі зробити детальний якісний аналіз прояву досліджуваної здатності у майбутніх лікарів.

Для більш детального аналізу результатів формуючого етапу дослідження ми порівняли зміни в середніх показниках прояву складових емоційного інтелекту на 2 та 3 етапах дослідження та визначили достовірність значущості цих змін після впровадження розробленої нами програми формування емоційної компетентності для майбутніх лікарів (Таблиця 2).

Таблиця 2

Порівняння результатів, отриманих за методикою дослідження емоційного інтелекту Д.В. Люсіна на другому та третьому етапах дослідження

\begin{tabular}{|c|c|c|c|c|}
\hline \multirow{2}{*}{$\begin{array}{c}\text { Показник емоційного інте- } \\
\text { лекту }\end{array}$} & \multicolumn{2}{|c|}{$\begin{array}{c}\text { Середнє значення } \\
\text { (в балах) }\end{array}$} & $\begin{array}{c}\text { Середній роз- } \\
\text { мір відхилен- } \\
\text { ня }\end{array}$ & $\begin{array}{c}\text { Т-критерій } \\
\text { Стьюдента }\end{array}$ \\
\cline { 2 - 3 } & $\begin{array}{c}2 \text { етап дослі- } \\
\text { дження }\end{array}$ & $\begin{array}{c}\text { етап дослі- } \\
\text { дження }\end{array}$ & 16,12 & $12,42^{* *}$ \\
\hline $\begin{array}{c}\text { Міжособистісний емоцій- } \\
\text { ний інтелект }\end{array}$ & $43,76 \pm 8,31$ & $60,11 \pm 5,57$ & 6,35 & $8,43^{* *}$ \\
\hline Розуміння чужих емоцій & $23,31 \pm 4,78$ & $29,70 \pm 3,39$ & 9,77 & $11,24^{* *}$ \\
\hline $\begin{array}{c}\text { Управління чужими емоці- } \\
\text { ями }\end{array}$ & $20,45 \pm 5,13$ & $30,40 \pm 3,81$ & 25,37 & $16,74^{* *}$ \\
\hline $\begin{array}{c}\text { Внутрішньо-особистісний } \\
\text { емоційний інтелект }\end{array}$ & $45,03 \pm 11,21$ & $70,65 \pm 5,75$ & 11,79 & $15,85^{* *}$ \\
\hline Розуміння власних емоцій & $19,67 \pm 5,91$ & $31,44 \pm 3,94$ & 6,23 & $9,92^{* *}$ \\
\hline $\begin{array}{c}\text { Управління власними емо- } \\
\text { ціями }\end{array}$ & $14,69 \pm 3,8$ & $21,21 \pm 2,54$ & 6,18 & $9,00^{* *}$ \\
\hline Контроль експресії & $11,67 \pm 4,4$ & $18,00 \pm 2,81$ & 18,14 & $17,16^{* *}$ \\
\hline Розуміння емоцій & $42,99 \pm 8,18$ & $61,14 \pm 5,59$ & 69,18 & $15,82^{* *}$ \\
\hline Управління емоціями & $46,81 \pm 9,22$ & $69,61 \pm 5,52$ & 22,18 & $18,85^{* *}$ \\
\hline Показник загального рівня & $88,79 \pm 16,05$ & $130,75 \pm 8,32$ & 41,49 & \multirow{2}{*nnn}{} \\
\hline
\end{tabular}


Визначена розбіжність за загальним показником емоційного інтелекту вказує на ефективність авторської програми формування емоційної компетентності у розвитку емоційного інтелекту майбутнього медика.

Результати аналізу показників за методикою «Визначення загальної емоційної спрямованості особистості» (Б. І. Додонов) на третьому етапі дослідження дали можливість побачити зміни у прояві загальної емоційної спрямованості майбутніх лікарів. Так, після впровадження програми 3 формування емоційної компетентності 13\% студентів мають праксичну емоційну спрямованість, тобто потребу активно діяти, досягати поставленої мети, домагатися бажаних результатів; 13\% комунікативну, що говорить про яскраво виражену потребу у спілкуванні; 12\% - романтичну, яскраво виражене прагнення до незвичайного, таємничого; 10\% - альтруїстичну, потребу віддавати, ділитися, сприяти, допома- гати, виражену спрямованість на інших; 12\% - гностичну; пов'язану з потребою в отриманні знань про нове, невідоме, задоволенні від процесу отримання знань; $12 \%$ - естетичну, потребу в сприйманні прекрасного, переживання сильних почуттів при сприйманні прекрасного; $8 \%$ - гедоністичну, коли емоції пов'язані із задоволенням потреби в тілесному і душевному комфорті, а комфортні умови для такої людини є дуже важливими, і досягнення комфорту є потужним мотивом діяльності; 10\% - глоричну, тобто яскраво виражену потребу у славі, переживання успіху на очах у інших людей, у популярності; 7\% - пугністичну, пов'язану з потребою ризикувати, долати небезпеку; 3\% - акизитивну, характеризує емоції, що виникають при наявності потреби в накопиченні (колекціонуванні) речей, що виходить за межі практичної потреби в них (Таблиця 3). Порівняльна характеристика зміни типів емоційної спрямованості та підрахунок

Таблиця 3

\section{Порівняння кількісних показників характеру прояву типів емоційної спрямованості у студентів на різних етапах дослідження}

\begin{tabular}{|l|c|c|c|}
\hline $\begin{array}{c}\text { Тип емоційної спрямо- } \\
\text { ваності }\end{array}$ & $\begin{array}{c}2 \text { етап дослідження } \\
(\%)\end{array}$ & $\begin{array}{c}3 \text { етап дослідження } \\
(\%)\end{array}$ & $\begin{array}{c}\text { 3начення } \varphi-~ \\
\text { Фішера }\end{array}$ \\
\hline Альтруїстична & 12 & 10 & 0,445 \\
\hline Комунікативна & 13 & 13 & 0 \\
\hline Глорична & 9 & 8 & 0,247 \\
\hline Праксична & 14 & 13 & 0,205 \\
\hline Пугністична & 7 & 7 & 0 \\
\hline Романтична & 12 & 12 & 0 \\
\hline Гностична & 12 & 12 & 0 \\
\hline Естетична & 11 & 12 & 0,219 \\
\hline Гедоністична & 9 & 10 & 0,247 \\
\hline Акизитивна & 1 & 3 & 1,047 \\
\hline
\end{tabular}


критерію Фішера у студентів на 2 та 3 етапах дослідження не показала нам достовірних змін. Це, на нашу думку, свідчить про те, що емоційна спрямованість $\epsilon$, до деякої міри, інтегративним компонентом у структурі емоційної компетентності, а тому іiі зміна потребує більшого часу та більш значущих змін у мотиваційній сфері особистості. В таблиці 4 представлено результати статистичного порівняння середніх балів за методикою Б.І. Додонова на другому та третьому етапах.

3 таблиці видно, що жодних статистично значущих відмінностей у прояві емоційних спрямованостей на другому та третьому етапі дослідження виявлено не було. Отримані нами результати ще раз підкреслюють нашу думку про те, що фахова підготовка фахівця, не може зводитися лише до отримання ним суми знань, формування вмінь та конкретних нави- чок. Вона, в першу чергу, повинна орієнтуватися на зміни в структурі особистості майбутнього лікаря, стрижневим моментом якої $є$ спрямованість, як сукупність потреб, мотивів, ідеалів, цілей, цінностей. Тільки формуючи ці складові, як основу, фундамент професійної підготовки, ми можемо вибудовувати всі фахові інструменти, що необхідні для ефективної роботи лікаря.

3 метою діагностики зміни в емпатійному компоненті емоційної компетентності майбутнього лікаря на цьому етапі дослідження нами також була використана методика діагностики рівня емпатійних здібностей (В.В. Бойко). Було проаналізовано показники значущості різних параметрів у структурі емпатії вже після впровадження програми 3 формування емоційної компетентності майбутнього лікаря.

Таблиця 4

Порівняння результатів, отриманих за методикою дослідження емоційної спрямованості Б. І. Додонова на другому та третьому етапах дослідження

\begin{tabular}{|c|c|c|c|c|}
\hline \multirow[b]{2}{*}{$\begin{array}{l}\text { Показник емоцій- } \\
\text { ної спрямованості }\end{array}$} & \multicolumn{2}{|c|}{ Середнє значення в балах } & \multirow[b]{2}{*}{$\begin{array}{c}\text { Середній розмір } \\
\text { відхилення }\end{array}$} & \multirow[b]{2}{*}{$\begin{array}{l}\text { Т-критерій } \\
\text { Стьюдента }\end{array}$} \\
\hline & $\begin{array}{c}2 \text { етап дослі- } \\
\text { дження }\end{array}$ & $\begin{array}{c}3 \text { етап дослі- } \\
\text { дження }\end{array}$ & & \\
\hline Альтруїстична & $6,14 \pm 2,35$ & $4,85 \pm 2,48$ & 1,26 & 1,73 \\
\hline Комунікативна & $6,60 \pm 2,17$ & $6,19 \pm 2,16$ & 0,25 & 0,56 \\
\hline Глорична & $4,95 \pm 2,74$ & $4,07 \pm 2,54$ & 0,82 & 1,50 \\
\hline Праксична & $7,17 \pm 1,96$ & $6,43 \pm 2,52$ & 0,72 & 1,74 \\
\hline Пугністична & $3,44 \pm 3,87$ & $3,52 \pm 3,07$ & 0,11 & 0,15 \\
\hline Романтична & $6,11 \pm 2,92$ & $6 \pm 2,42$ & $-0,09$ & $-0,16$ \\
\hline Гностична & $6,17 \pm 2,26$ & $6,12 \pm 3,01$ & 0,19 & 0,44 \\
\hline Естетична & $5,94 \pm 3,14$ & $5,71 \pm 3,24$ & 0,11 & 0,16 \\
\hline Гедоністична & $4,70 \pm 3,55$ & $4,92 \pm 2,65$ & $-0,54$ & $-0,92$ \\
\hline Акизитивна & $0,70 \pm 3,98$ & $1,63 \pm 3,28$ & $-1,04$ & $-1,54$ \\
\hline
\end{tabular}


Порівняльний аналіз зміни значущості різних параметрів в структурі емпатії у студентів на 2 та 3 етапах дослідження показав, що практично всі параметри в структурі емпатії проявилися на більш високому рівні. Для встановлення статистичної достовірності відмінностей між виділеними показниками, була перевірена значущість різниці середніх показників всіх параметрів в структурі емпатії (Таблиця 5).

Статистичний аналіз дозволив підтвердити припущення про те, що всі прояви емпатії у майбутніх медиків суттєво підвищилися на третьому у порівнянні з результатами другого етапу.

Узагальнюючи результати дослідження емпатійного компоненту емоційної компетен- тності на даному етапі дослідження нами також був проаналізований і загальний рівень розвитку емпатії у майбутніх лікарів.

Можемо констатувати суттєві зміни у розвитку цієї важливої характеристики. Так, після впровадження програми 3 формування емоційної компетентності занижений рівень емпатії мають лише $21 \%$ студентів (замість 72\% на попередньому етапі дослідження), збільшилась кількість майбутніх лікарів із середнім рівнем - 39\% (15\% на попередньому етапі); високий рівень емпатії мають $31 \%$ майбутніх лікарів (на відміну від 0\% на попередньому етапі дослідження), в а лише 9\% - дуже низький рівень (замість 13\% на попередньому етапі). Такі кількісні результати показали нам позитивну динаміку змін, що продемонструва-

Таблиця 5

\section{Порівняння результатів, отриманих за методикою дослідження емпатії B.В. Бойка на другому та третьому етапах дослідження}

\begin{tabular}{|c|c|c|c|c|}
\hline \multirow{2}{*}{ Показник емпатії } & \multicolumn{2}{|c|}{$\begin{array}{c}\text { Середнє значення } \\
\text { (в балах) }\end{array}$} & \multirow{2}{*}{$\begin{array}{c}\text { Середній роз- } \\
\text { мір відхилен- } \\
\text { ня }\end{array}$} & \multirow{2}{*}{$\begin{array}{l}\text { Т-критерій } \\
\text { Стьюдента }\end{array}$} \\
\hline & $\begin{array}{c}2 \text { етап дослі- } \\
\text { дження }\end{array}$ & $\begin{array}{c}3 \text { етап дослі- } \\
\text { дження }\end{array}$ & & \\
\hline Раціональний & $2,98 \pm 1,3$ & $4,03 \pm 1,33$ & 1,19 & $5,639^{* *}$ \\
\hline Емоційний & $2,74 \pm 1,55$ & $3,98 \pm 1,7$ & 1,47 & $5,142^{* *}$ \\
\hline Інтуїтивний & $2,71 \pm 1,48$ & $4,07 \pm 1,85$ & 1,51 & $4,855^{* *}$ \\
\hline $\begin{array}{c}\text { Установки які сприяють } \\
\text { емпатії } \\
\end{array}$ & $3,13 \pm 1,42$ & $4,42 \pm 1,19$ & 1,47 & $6,886^{* *}$ \\
\hline Здатність до емпатії & $3,10 \pm 1,11$ & $4,26 \pm 1,09$ & 1,26 & $6,052^{* *}$ \\
\hline Ідентифікація в емпатії & $3,43 \pm 1,31$ & $4,70 \pm 1,14$ & 1,40 & $6,524^{* *}$ \\
\hline Зальний бал & $18,17 \pm 3,87$ & $25,15 \pm 6,48$ & 8,00 & $11,67^{* *}$ \\
\hline
\end{tabular}


ло проведене лонгитюдне дослідження та впроваджена нами програма формування емоційної компетентності майбутнього лікаря в структурі навчального процесу, а також загальну тенденцію до зменшення фахівців із заниженим рівнем емпатії і підвищенням кількості студентів, що показали середній та високий рівень.

Порівняльна характеристика зміни рівня прояву емпатії у студентів на 2 та 3 етапах дослідження (у \%) представлена у таблиці 6.

Підрахунок критерію Фішера дозволив визначити статистично значуще збільшення на третьому етапі кількості студентів з середнім $(\varphi=3,917, p \leq 0,01)$ та високим $(\varphi=6,937$, $\mathrm{p} \leq 0,01)$ рівнем емпатії, та статистично значуще зменшення кількості студентів з заниженим $(\varphi=7,594, p \leq 0,01)$ рівнем емпатії.
Якщо говорити про структуру перешкод у спілкуванні, то на цьому етапі дослідження всі «перешкоди» мали місце і були виділені у відповідях студентів. Разом 3 тим, ми помітили значно нижчий рівень прояву даних «перешкод» після застосування тренінгової програми: невміння керувати емоціями та ïx неадекватний прояв (середній показник $1,1)$, небажання зближатися 3 людьми на емоційній основі (середній показник - 1,3), домінування негативних емоцій (середній показник - 1,2), неадекватний прояв емоцій (середній показник - 1,9), негнучкість (середній показник - 0,9).

На основі кількісного підрахунку результатів, можемо констатувати, що на третьому (формуючому) етапі дослідження відбулися суттєві зміни у рівні вияву «перешкод» у

Таблиця 6

\section{Порівняння кількісних показників зміни рівня прояву емпатії у студентів}

\begin{tabular}{|c|c|c|c|}
\hline $\begin{array}{c}\text { Показники рівня прояву ем- } \\
\text { патії }\end{array}$ & $\begin{array}{c}2 \text { етап дослідження } \\
(\%)\end{array}$ & $\begin{array}{c}3 \text { етап дослідження } \\
(\%)\end{array}$ & $\begin{array}{c}\text { 3начення } \varphi- \\
\text { Фішера }\end{array}$ \\
\hline дуже низький рівень емпатії & 13 & 9 & 0,912 \\
\hline занижений рівень емпатії & 72 & 21 & $7,594^{* *}$ \\
\hline середній рівень емпатії & 15 & 39 & $3,917^{* *}$ \\
\hline високий рівень емпатії & 0 & 31 & $6,937^{* *}$ \\
\hline
\end{tabular}

На третьому етапі дослідження нами також була проведена методика діагностики «перешкод» у встановленні емоційних контактів (В. В. Бойко) з метою виявлення змін, що в результаті впровадженої програми відбулися. встановленні емоційних контактів, що, на нашу думку, свідчить про ефективність розробленої нами програми формування емоційної компетентності майбутнього лікаря в структурі навчального процесу, а також необхідність пода- 
льшої роботи, спрямованої на розвиток відповідних навичок студентів та подолання «перешкод», що заважатимуть їм у подальшій професійній діяльності.

Нами також був проведений порівняльний аналіз рівня прояву «перешкод» у встановленні емоційних контактів на 2 та 3 етапах дослідження. Порівняльна характеристика середніх показників рівня прояву «перешкод» у встановленні емоційних контактів на другому та третьому етапах дослідження представлена у таблиці 7.

Як бачимо, у результаті дослідження отримаємо підтвердження про доцільність впровадження програми з формування емоційної компетентності майбутнього лікаря, оскільки отримані показники, в тому числі з виявлення «перешкод» у встановленні емоційних контактів на двох етапах свідчать про суттєві зміни основних показників у обстежуваних студентів. Додамо лише, що гармонійний розвиток усіх складових досліджуваного конс- трукту характерний тільки для високорозвиненої емоційної компетентності.

Разом 3 тим, співставлення результатів другого та третього етапів дослідження дозволило нам прослідкувати зміни у прояві соціального, когнітивного, регулятивного, емпатійного компонентів емоційної компетентності у студентів після впровадженої нами програми формування емоційної компетентності майбутніх лікарів. Так, когнітивний компонент визначався нами за такими характеристиками, як емоційна зрілість (емоційна обізнаність), розуміння власних емоційних станів, адекватна самооцінка (знання власних сил та меж), мотивація до розвитку власної емоційної компетентності. На третьому етапі дослідження, зміни в середніх показниках по шкалі «Емоційна обізнаність» хоча і залишилися на середньому рівні, разом з тим показали позитивну якісну динаміку (9,33 - на 2 етапі та 12,61 - на 3 етапі), що, в свою чергу, підвищило загальний рівень вмотивованості студентів

Таблиця 7

Порівняльна характеристика середніх показників рівня прояву «перешкод» у встановленні емоційних контактів (2 та 3 етапи дослідження)

\begin{tabular}{|c|c|c|}
\hline Характер «перешкод» & $\begin{array}{c}2 \text { етап дослі- } \\
\text { дження (середні } \\
\text { показники) }\end{array}$ & $\begin{array}{c}\text { етап дослі- } \\
\text { дження } \\
\text { (середні показ- } \\
\text { ники) }\end{array}$ \\
\hline Невміння керувати емоціями, дозувати їх & 2,23 & 1,1 \\
\hline Неадекватний прояв емоцій & 2,32 & 1,9 \\
\hline Домінування негативних емоцій & 1,92 & 1,2 \\
\hline Негнучкість & 1,76 & 0,9 \\
\hline Небажання зближатися з людьми на емоційній основі & 2,1 & 1,3 \\
\hline Загальний рівень & $\mathbf{1 0 , 4}$ & $\mathbf{7 , 3}$ \\
\hline
\end{tabular}


до самовдосконалення, та розвитку власних професійних компетенцій

(шкала «Самомотивація» 6,84 - на 2 етапі, що відповідає низькому рівню, і 9,38 - на 3 етапі, що відповідає середньому рівню). Студенти на 3 етапі дослідження виявляли значно кращі результати в усвідомленні власних емоцій, їх характеру і причин появи, а також здатності їх описати (19, 7 - на 2 етапі та 31,44 - на 3 етапі). Стандартне відхилення становило 3,94 бали (12,53\%). Розбіжність склала 11,79 бали та виявилася значущою ( $\mathrm{T}=15,85, \mathrm{p} \leq 0,01)$. Отже, на третьому етапі ми спостерігаємо суттєве підвищення здатності до розпізнавання власних емоційних станів та аналізу амбівалентних почуттів. Тобто, у студентів на третьому етапі дослідження когнітивний компонент виявлявся за деякими показниками на середньому рівні розвитку (усвідомленні власних емоцій, їх характеру і причин появи, а також здатності їх описати), хоча загальна якісна динаміка розвитку була позитивною. Досягненням у формуванні когнітивного компоненту ми вважаємо визначний якісний стрибок в усвідомленні власних переживань. Діалоговий характер розробленої нами програми та рефлексія власної діяльності, як основний метод формування когнітивного компоненту емоційної компетентності, створили підгрунтя для розвитку можливості усвідомлювати, розпізнавати та ідентифікувати власні емоції, а також вербально описувати їх, з метою розуміння причин виникнення та перебігу.
Соціальний компонент у структурі емоційної компетентності розглядався нами через сформованість оптимістичного ставлення до взаємодії з іншими людьми, через рівень емоційної ефективності у спілкуванні, прояв певного типу емоційної спрямованості, вміння розпізнавати емоції інших а також визначенням тих емоційних «перешкод», що заважають успішній комунікації в повсякденному житті. В результаті запровадженої нами програми формування емоційної компетентності для майбутніх лікарів здатність студентів розуміти емоційний стан людини $(29,7)$ на основі зовнішніх проявів емоцій (міміка, жести, звучання голосу), чуйність до внутрішнього стану інших людей та здатність викликати в інших людях ті чи інші емоції, знижувати інтенсивність небажаних емоцій знаходиться на високому рівні $(30,4)$, що ще раз свідчить про необхідність цілеспрямованої організації підготовки фахівця, яка б обов'язково передбачала формування особистісних компетенцій, в тому числі, у сфері емоцій. Визначені на третьому етапі дослідження статистично значущі відмінності свідчать про суттєве зростання не тільки рівня розуміння емоцій інших людей майбутніми медиками, а й вміння управляти ними, що, в свою чергу дозволить майбутньому фахівцеві ефективно будувати взаємодію 3 пацієнтом у лікувальному процесі. Вивчення соціального компоненту дозволило виділити суттєві зміни, які відбулися у рівні вияву «перешкод» у встановленні емоційних контак- 
тів, що, на нашу думку, ще раз підкреслює ефективність розробленої нами програми формування емоційної компетентності майбутнього лікаря в структурі навчального процесу. Статистично значуще зменшення кількості досліджуваних, яким емоції явно заважали встановлювати контакти $(\varphi=3,182, p \leq 0,01)$ та яким емоції щодня деякою мірою ускладнювали взаємодію $(\varphi=4,815, p \leq 0,01)$, а також значущий ріст осіб, яким емоції зазвичай не заважають у спілкуванні $(\varphi=5,233, \mathrm{p} \leq 0,01)$, засвідчило про суттєве зменшення осіб, що зіштовхуються у міжособистісному спілкуванні з емоційними проблеми та перешкодами. Такі результати у формуванні соціального компоненту емоційної компетентності довели виправданість розробленої нами програми та відповідної методики.

Аналіз основних характеристик регулятивного компоненту: управління власними внутрішніми станами, наявність негативних проявів у функціонуванні емоційної сфери, емоційний самоконтроль, емоційна резистентність, самоконтроль експресії показав нам, що студенти, які не вміють адекватно оцінювати власні емоції, описувати їх та не усвідомлюють причини їх виникнення, не здатні керувати своїми емоціями, викликати та підтримувати бажані емоції та тримати під контролем небажані i, зазвичай, контролювати зовнішні прояви своїх емоцій. Даний компонент у структурі емоційної компетентності на третьому етапі дослідження кількісно характеризувався значно вищими результатами, що підкреслює позитивні зміни у формуванні емоційної обізнаності та соціально значущих форм емоційної взаємодії з іншими у процесі спілкування. Отже, ми сміливо можемо говорити про формування культури емоційної поведінки особистості, що дає їй змогу довільно впливати на власні емоції та емоції інших, керувати ставленням людей до себе, що дозволяє особистості фахівця мотивувати саму себе й інших. Так, на третьому етапі розбіжність за показником «Управління власними емоціями» склала 6,23 бали та виявилася значущою ( $\mathrm{T}=9,92$, $\mathrm{p} \leq 0,01)$, а розбіжність за показником «Контроль експресії» склала 6,18 бали та виявилася значущою ( $\mathrm{T}=9, \mathrm{p} \leq 0,01)$. На третьому етапі дослідження майбутні медики показали не лише значно більшу здатність до контролю зовнішнього прояву емоцій, а й продемонстрували розвинену здатність до управління власними емоційними станами. Таким чином, ми спостерігаємо, що інтегративний показник по регулятивному компоненту зазнав статистично значущого розвитку на третьому етапі дослідження.

Вивчення емпатійного компоненту в структурі емоційної компетентності мало для нас особливе значення, адже емпатія складає основу довіри до лікаря і прихильності пацієнта до лікування. Порівняльний аналіз кількісних характеристик за інтегративним показником емпатії на другому етапі дослідження склав 18,17 бали зі стандартним відхиленням 
3,87 бали (21,29\%), що відповідає пониженому рівню емпатії. На третьому етапі цей показник склав 25,15 бали зі стандартним відхиленням 6,48 бали $(25,76 \%)$, що відповідає середньому рівню емпатії. Розбіжність склала 8 балів та виявилася статистично значущою ( $\mathrm{T}=11,67, \mathrm{p} \leq 0,01)$. Визначена розбіжність вказує на високу ефективність авторської програми розвитку емоційної компетентності у розвитку емпатійних здібностей. I хоча ми констатували лише середній рівень прояву емпатії, ii якісна динаміка формування доводить, що задля розвитку особистісних характеристик майбутнього фахівця необхідно розробляти цілеспрямовану програму впливу на його особистість 3 метою розвитку професійно значущих якостей та компетенцій. Ми вважаємо, що саме формування емпатійного компоненту $\epsilon$ стрижневим завданням у підготовці майбутнього фахівця, оскільки саме він перетворює лікувальний процес із суто технічної взаємодії на особистісну.

Висновки. Після впровадження спеціальної програми формування емоційної компетентності майбутнього лікаря нами були проаналізовані кількісні зміни у показниках складових емоційної компетентності та їх значущість. Основним результатом впровадження психологічної програми формування емоційної компетентності майбутнього лікаря стало підвищення рівня розвитку компетенцій студентів-медиків у сфері емоцій. Як показали результати дослідження, прояв соціального, когнітивного, регулятивного, емпатійного компонентів емоційної компетентності у студентів набув статистично значущих позитивних якісних змін. Мова йде про позитивну динаміку розвитку емоційної компетентності та iii структурних компонентів у майбутніх лікарів, розвиток навичок усвідомлення, управління, контролю своїх емоцій та емоцій інших, розвиток емпатії, підвищення самооцінки, впевненості у собі тощо. Це дозволило студентам - майбутнім лікарям по завершенню дослідження відчути більшу впевненість у власній професійній компетентності через підвищення емоційної зрілості, можливості краще розуміти власні емоційні стани, сформованої мотивації до розвитку власної емоційної компетентності та оптимістичного ставлення до взаємодії 3 іншими людьми. Формування вміння розпізнавати емоції інших людей, а також визначення тих емоційних «перешкод», що заважають успішній комунікації у повсякденному житті дозволило студентам навчитися краще управляти власними внутрішніми станами, контролювати та справлятися 3 проявом негативних емоцій, здійснювати емоційний самоконтроль, проявляти емпатію, яка складає основу довіри до лікаря і прихильності пацієнта до лікування.

Таким чином, результатами проведеного експериментально-психологічного дослідження нами було продемонстровано динаміку змін у розвитку емоційної сфери студентівмедиків в результаті впровадження спецкурсу 
«Психологія емоцій», проведення тренінгу «Формування емоційної компетентності» із застосуванням сучасних психотехнологій, а відтак, доведено ефективність запропонованої програми формування всіх компонентів емоційної компетентності майбутніх лікарів, що демонструє необхідність та доцільність якісних змін у професійній підготовці фахівців.

\section{Перспективи подальших розвідок} полягають у нових наукових дослідженнях 3 даної проблематики, а також в практичній діяльності, спрямованій на розвиток емоційної сфери особистості при підготовці майбутніх фахівців в галузі медицини, психології, педагогіки.

\section{Перелік використаних джерел:}

1. Лазуренко О.О. Психологія емоцій в структурі підготовки фахівців у вищих навчальних закладах медичного профілю/ О. О. Лазуренко// Педагогіка та психологія: традиції та інновації: Матеріали міжнародної науково-практичної конференції. - Львів, 2013. - С.22-25.

2. Лазуренко О.О. Концепція формування емоційної компетентності на різних етапах професійної підготовки лікаря /О. О. Лазуренко // Науковий вісник Херсонського державного університету. Серія: Психологічні науки. - Випуск 3. - Херсон, 2015. - С. 113-117.

3. Лазуренко О.О. Експериментальне дослідження психологічних особливостей емоційної компетентності майбутнього лікаря/ О.О. Лазуренко// Актуальні проблеми психології: Зб.наук. праць Ін-ту психології імені Г.С.Костюка НАПН України. - Том 5. Випуск 15. - Київ, 2015. - С. 106-114.

4. Лазуренко О.О. Тренінг формування емоційної компетентності майбутнього лікаря/ О. О. Лазуренко//
Fundamental and Applied Researches In Practice of Leading Scientific Schools. - 2016. - 2 (14).

5. Лазуренко О.О., Тертична Н.А. Дослідження психологічних складових емоційної компетентності майбутнього фахівця-лікаря./ О.О. Лазуренко, Н.А. Тертична// Актуальні проблеми психології: Зб.наук. праць Ін-ту психології імені Г.С. Костюка НАПН України. - Том Х. Психологія навчання. Генетична психологія. Медична психологія. - Вип. 29. - Київ, 2016. - С. 97-106.

6. Лазуренко О.О. Аналіз психологічних особливостей складових емоційної компетентності майбутнього лікаря./ О.О. Лазуренко// Психологічний часопис. Збірник наукових праць. - №2(4)2016. - С. 96-111.

7. Olena O. Lazurenko, Nataliya V.Smila. Psychological and Pedagogical Principles of Students' Emotional Sphere formation in the Process of Professional Training and Development.// Journal of Psychological Sciences. - Vol.2. No.3. - 2016. PP. 124-129.

\section{References (Transliteration):}

1. Lazurenko O.O. PsihologIya emotsIy $\mathrm{v}$ strukturI pIdgotovki fahIvtsIv u vischih navchalnih zakladah medichnogo profllyu/ O. O. Lazurenko// PedagogIka ta psihologIya: traditsIYi ta InnovatsIYi: MaterIali mIzhnarodnoYi naukovo-praktichnoYi konferentsIYi. LvIv, 2013. - S.22-25.

2. Lazurenko O.O. KontseptsIya formuvannya emotsIynoYi kompetentnostI na rIznih etapah profesIynoYi pIdgotovki IIkarya /O. O. Lazurenko // Naukoviy vIsnik Hersonskogo derzhavnogo unIversitetu. SerIya: PsihologIchnI nauki. Vipusk 3. - Herson, 2015. - S. 113-117.

3. Lazurenko O.O. TrenIng formuvannya emotslynoYi kompetentnostI maybutnogo IIkarya/ O. O. Lazurenko// Fundamental and Applied Researches In Practice of Leading Scientific Schools. - 2016. - 2 (14).

4. Lazurenko O.O. Eksperimentalne doslIdzhennya psihologIchnih osoblivostey emotslynoYi kompetentnostI maybutnogo IIkarya/ O.O. Lazurenko// AktualnI problemi psihologIYi: Zb.nauk. prats In-tu psihologIYi ImenI 
G.S.Kostyuka NAPN UkraYini. - Tom 5. Vipusk 15. KiYiv, 2015. - S. 106-114.

5. Lazurenko O.O., Tertichna N.A. DoslIdzhennya psihologIchnih skladovih emotsIynoYi kompetentnostI maybutnogo fahIvtsya-lIkarya./ O.O. Lazurenko, N.A. Tertichna// AktualnI problemi psihologIYi: Zb.nauk. prats In-tu psihologIYi ImenI G.S. Kostyuka NAPN UkraYini. Tom H. PsihologIya navchannya. Genetichna psihologIya. Medichna psihologIya. - Vip. 29. - KiYiv, 2016. - S. 97106.

6. Lazurenko O.O. AnalIz psihologIchnih osoblivostey skladovih emotsIynoYi kompetentnostI maybutnogo 1Ikarya./ O.O. Lazurenko// PsihologIchniy chasopis. ZbIrnik naukovih prats. - \#2(4)2016. - S. 96-111.

7. Olena O. Lazurenko, Nataliya V.Smila. Psychological and Pedagogical Principles of Students' Emotional Sphere formation in the Process of Professional Training and Development.// Journal of Psychological Sciences. - Vol.2. No.3. - 2016. PP. 124-129.

\section{Lazurenko Olena Oleksiivna}

Senior Lecturer, Department of General and Medical Psychology and Pedagogy Bogomolets National Medical University, Kyiv (Ukraine)

\section{CHANGES IN THE DEVELOPMENT OF MEDICAL STUDENTS EMOTIONAL COMPETENCE AS THE RESULT OF SPECIAL COURSE INTRODUCTION AND PSYCHOTRAINING APPLICATION}

\begin{abstract}
The article studies psychological and pedagogical components of the emotional competence formation of future doctors at different phases of training. Main aspects of future doctors' professional training at higher medical educational institutions are also described. Author attempts to
\end{abstract}

disclose the specifics of future specialists' emotional-psychological competence formation. The concept of formation of emotional competence of a specialist is suggested.

The problem of the formation of emotional competence of future doctors is one of the most important in the field of professional medical education. Analysis of state educational standard of higher medical education has shown that some of the disciplines hereunder, allow students to obtain information about the psychological aspects of the emotional sphere, the emotional organization of personality, age-related peculiarities of this phenomenon, as well as the basics of control of emotional states. The results of the analysis of curricula and training programs of medical specialists indicate that the psychology of emotions is not a separate object of pedagogical influence, and therefore there is an objective contradiction between the real needs of the future specialist in acquisition of knowledge on the psychology of emotions and the ability to get them in the learning process in higher medical schools. The results of our analysis allowed us to establish that today the problem of the formation of emotional competence of a future specialist is new in the field of psychological research. However, in our deep conviction, it is advisable to figure out how to solve this problem in practice, at higher medical education.

Today, there are available and used a variety of exercises, tasks, seminars, workshops aimed at the development of the emotional 
sphere, and emotional competence of the student, which can be suggested as an additional material in the process of theoretical and practical training of future doctors in higher medical educational establishments. The experimental research of psychological features of the future doctor emotional competence and analysis of its structural components are presented in the article. Based on the results of a search phase of the study of the formation of emotional competence of future doctors, tasks were identified and hypothesized pilot study. The techniques of empirical research are show. Empirical data, results of processing and analysis of the basis for the development of the program of special training of students - future doctors are described. On the basis of generalization of the obtained results identify ways of promoting professional competences in the field of emotions. Set out the overall strategy, the structure, revealed the main principles, methodological approaches and content of training programs aimed at developing the emotional competence of students - future doctors. The positive results of the carried-out work on formation of emotional competence of students-future doctors dictate the urgent need to continue initiated activities to improve the educational process in higher medical educational establishment.

Keywords: emotional competence, diagnostics of the psychological characteristics of emotional competence, future doctor personality, emotional competence development, training course.

\section{Лазуренко Елена Алексеевна}

Стариий преподаватель кафедры общей и медицинской психологии и педагогики Национального медиџинского университета имени А.А. Богомольца, г. Киев (Украина)

\section{ДИНАМИКА ИЗМЕНЕНИЙ В РАЗВИТИИ ЭМОЦИОНАЛЬНОЙ КОМПЕТЕНТНО- СТИ СТУДЕНТОВ-МЕДИКОВ КАК РЕ- ЗУЛЬТАТ ПРОВЕДЕНИЯ СПЕЦКУРСА И ИСПОЛЬЗОВАНИЯ ТРЕНИНГОВЫХ ПСИХОТЕХНОЛОГИЙ}

Аннотация. Исследование эмоциональной компетентности будущих врачей в условиях высшего профессионального образования обусловлена необходимостью выявления ее психологических составляющих и особенностей формирования эмоциональной сферы. Результаты анализа учебных планов и программ подготовки медицинских специалистов указывают на то, что психология эмоций не выделяется в отдельный объект педагогического воздействия. Основываясь на результатах поискового этапа исследования формирования эмоциональной компетентности будущего врача, учитывая большую профессиональную важность формирования этого феномена, встала проблема поиска определенных потенциалов профессиональной подготовки в ее решении. Целесообразность проведения тренинговых занятий по формированию эмоциональной компетентности будущего врача обусловлена теоретическим анализом и результатами проведенного экспериментального исследования.

После внедрения специальной программы формирования эмоциональной компе- 
тентности будущего врача нами были проанализированы количественные изменения в показателях составляющих эмоциональной компетентности и их значимость. Основным результатом внедрения психологической программы формирования эмоциональной компетентности будущего врача является повышение уровня развития компетенций студентовмедиков в сфере эмоций. Как показали результаты исследования, проявление социального, когнитивного, регулятивного, емпатійного компонентов эмоциональной компетентности у студентов приобрел статистически значимых положительных качественных изменений. Речь идет о положительной динамике развития эмоциональной компетентности и ее структурных компонентов у студентов - будущих врачей, развитие навыков осознания, управления, контроля своих эмоций и эмоций других, развитие эмпатии, повышение самооценки, уверенности в себе и тому подобное. Это позволило будущим врачам по завершению исследования ощутить большую уверенность в собственной профессиональной компетентности через повышение эмоциональной зрелости, возможности лучше понимать собственные эмоциональные состояния, сформированной мотивации к развитию собственной эмоциональной компетентности и оптимистического отношения к взаимодействию с другими людьми. Формирование умения распознавать эмоции других людей, определение тех эмоциональных «помех», которые мешают успешной коммуникации в повседневной жизни, позволило студентам научиться лучше управлять собственными внутренними состояниями, контролировать и справляться с проявлением негативных эмоций, осуществлять эмоциональный самоконтроль, а также проявлять эмпатию, что составляет основу доверия к врачу и приверженности пациента к лечению. Таким образом, результатами проведенного экспериментально-психологического исследования нами было продемонстрировано динамику изменений в развитии эмоциональной сферы студентов-медиков в результате применения тренинговых психотехнологий, а следовательно, доказана эффективность предложенной программы формирование всех компонентов эмоциональной компетентности будущих врачей

Ключевые слова: эмоциональная компетентность, развитие, диагностика психологических особенностей эмоциональной компетентности, личность будущего врача, спецкурс, тренинговая программа, профессиональная подготовка

Дата отримання статті: 29.02.2017 Дата рекомендації до друку: 03.03.2017 